Article

\title{
User Acceptance of Smart Watch for Medical Purposes: An Empirical Study
}

\author{
Rana Saeed Al-Maroof ${ }^{1}$, Khadija Alhumaid ${ }^{2}$, Ahmad Qasim Alhamad ${ }^{3}$, Ahmad Aburayya ${ }^{4}(\mathbb{D}$ \\ and Said Salloum $5,6, *$ (D) \\ 1 English Language \& Linguistics Department, Al Buraimi University College, Al Buraimi 512, Oman; \\ rana@buc.edu.om \\ 2 College of Education, Zayed University, Abu Dhabi P.O. Box 19282, United Arab Emirates; \\ khadija.alhumaid@zu.ac.ae \\ 3 Information Systems Department, University of Sharjah, Sharjah P.O. Box 26666, United Arab Emirates; \\ aalhamad@sharjah.ac.ae \\ 4 Quality \& Corporate Development Office, Dubai Health Authority, Dubai 9115, United Arab Emirates; \\ amaburayya@dha.gov.ae \\ 5 School of Science, Engineering, and Environment, University of Salford, Salford M5 4WT, UK \\ 6 Machine Learning and NLP Research Group, University of Sharjah, Sharjah 27272, United Arab Emirates \\ * Correspondence: salloum78@live.com; Tel.: +971-(050)-7679647
}

check for updates

Citation: Al-Maroof, R.S.; Alhumaid, K.; Alhamad, A.Q.; Aburayya, A.; Salloum, S. User Acceptance of Smart Watch for Medical Purposes: An Empirical Study. Future Internet 2021, 13, 127. https://doi.org/10.3390/ fi13050127

Academic Editor: Matthew Pediaditis

Received: 12 April 2021

Accepted: 10 May 2021

Published: 12 May 2021

Publisher's Note: MDPI stays neutral with regard to jurisdictional claims in published maps and institutional affiliations.

Copyright: (c) 2021 by the authors. Licensee MDPI, Basel, Switzerland. This article is an open access article distributed under the terms and conditions of the Creative Commons Attribution (CC BY) license (https:/ / creativecommons.org/licenses/by/ $4.0 /)$.

\begin{abstract}
This study aims to investigate the most effective and interesting variables that urge use of the smartwatch (SW) in a medical environment. To achieve this aim, the study was framed using an innovative and integrated research model, which is based on combining constructs from a well-established theoretical model's TAM and other features that are critical to the effectiveness of SW which are content richness and personal innovativeness. The Technology Acceptance Model (TAM) is used to detect the determinants affecting the adoption of SW. The current study depends on an online questionnaire that is composed of (20) items. The questionnaire is distributed among a group of doctors, nurses, and administration staff in medical centers within the UAE. The total number of respondents is (325). The collected data were implemented to test the study model and the proposed constructs and hypotheses depending on the Smart PLS Software. The results of the current study show that the main constructs in the model contribute differently to the acceptance of SW. Based on the previous assumption, content richness and innovativeness are critical factors that enrich the user's perceived usefulness. In addition, perceived ease of use was significantly predictive of either perceived usefulness or behavioral intention. Overall findings suggest that SW is in high demand in the medical field and is used as a common channel among doctors and their patients and it facilitates the role of transmitting information among its users. The outcomes of the current study indicate the importance of certain external factors for the acceptance of the technology. The genuine value of this study lies in the fact that it is based on a conceptual framework that emphasizes the close relationship between the TAM constructs of perceived usefulness and perceived ease of use to the construct of content richness, and innovativeness. Finally, this study helps us recognize the embedded motives for using SW in a medical environment, where the main motive is to enhance and facilitate the effective roles of doctors and patients.
\end{abstract}

Keywords: smart watch; Technology Acceptance Model; content richness; innovativeness

\section{Introduction}

The Internet of Things (IoT) has evolved rapidly during recent years, urging its users to make use of various information anywhere and anytime. Part of (IoT) is the smartwatch and other wearable technology devices. The widespread use of these devices enables their users to have immediate access to different medical information and physical activities [1-4]. Companies have recently developed and sold smartwatches. Its selling 
percentage is getting higher and higher over time. The specific features of Smartwatches urge many users to adopt this technology; these features include pairing with mobile phones to expose different phone features, providing notification, providing watch faces and timekeeping capabilities [5-8]. Wearable devices have appeared as a significant tool that can help measure physiological parameters such as heart rate and arterial blood pressure to reach the final goal, which enhances healthcare efficiency $[9,10]$. To put in other words, SW is useful in the medical field because it combines features of smartphones as well as providing prompt feedback permitting a fast communication process between patients and doctors. SW popularity has urged many doctors and patients to depend on their unique features including performing timely interventions, health monitoring systems, and fitness systems [11,12].

Accordingly, the demand to use this type of technology has increased in different areas and the medical environment is not an exception. Smartwatches undertake different medical tasks including carbohydrate, blood glucose, and insulin unit entry, viewing all required previously recorded values and the recording of required physical activities $[13,14]$. The eagerness to develop more medical-specific features urges researchers to tackle this issue in more detail. Accordingly, the main contributions of the current study can be summarized as follows: Firstly, the study investigates the effects of antecedents of SW adoption directly and indirectly. This can be implemented using an innovative and integrated research model to enhance the understanding of the determinants of SW adoption. In other words, a conceptual model was developed that combines the TAM acceptance model [15] and diffusion of innovation (DOI) theory [16] to highlight the significance and predictableness of the results. Secondly, the current study aims to evaluate the success of SW adoption within a medical field, which can be of huge interest to doctors and patients. Users in the medical field are increasingly keen to develop their future benefits and pave the way for further recommendations. It has been recognized that SW acceptance is relevant to more than the decision of individual users but rather to the use of the community. The information can be shared in a group of communities within a restricted social group of doctors and patients to diffuse their attitudes and behaviors. Thirdly, this study has adopted an external variable, that is, specific to the importance of smartwatch's external features in the medical field. This study sets its external factors apart from previous studies by $[17,18]$, which focused on availability and mobility. In fact, the current research includes innovations and content richness as the core of smartwatch external factors.

The main contribution of this paper is that it investigates the efficiency of SW from a purely medical perspective, where the acceptance of the SW is based on important TAM factors' perceived ease of use and perceived usefulness from the doctors' and patients' points of view. What sets this paper apart from previous research is the fact that it focuses on two variables that facilitate the acceptance of wearable technology, which are personal innovativeness and content richness. The effectiveness of these two variables leads to a higher level of SW acceptance. To the best of our knowledge, this is the first attempt to measure the acceptance of SW within the medical field, depending on an integrated model to fill a significant research gap in the relevant literature.

\section{Literature Review}

The adoption of the smartwatch has been the main concern of researchers in Malaysia, Korea, and Taiwan, where surveys are used among participants as a tool to collect data. The difference lies in the choice of external factors. Studies by $[17,18]$ have adopted different external factors; the former focuses on availability and mobility whereas the latter focuses on novelty and social dimension. Other external factors, such as relative advantage, complexity and design aesthetics, are the dominant factors of a study by [19] in Taiwan. Furthermore, ref. [17] asserted that the adoption of the smartwatch may have psychological implications.; therefore, their set of external factors has deviated from other studies. A similar study by [20] focuses on availability and attitude as external factors which affect the usage of smartwatches. 
Recently, it seems that the smartwatch has influentially affected its users. One study has determined the effectiveness of smartwatches by focusing on users' attitudes in different places all over the world. It creates a sort of comparative analysis that shows that there is a significant difference, as far as availability is concerned, between France and Thailand. There is also a difference between France and China concerning the trust aspect. References [21,22] focused on wearable devices and connected them with different external factors including mobility, trust, cost, usefulness, enjoyment and so forth. Table 1 illustrates the main external factors that are traced in the previous studies along with the tool used, participants, and place of implementing the tool. Table 1 shows the studies that tackled SW acceptance and adoption. It is worth mentioning that the final goal of these studies may vary. Generally speaking, acceptance studies focus on the positives decisions that are made by users, which leads to understanding the behavioral attention of technology [23-26]. On the contrary, adoption studies are intended to focus on predicting users' behavior towards the effectiveness of the new technology [26].

Table 1. Studies on Smartwatch Adoption/Acceptance.

\begin{tabular}{|c|c|c|c|c|c|c|}
\hline Author(s) & $\begin{array}{l}\text { Country or } \\
\text { Place }\end{array}$ & Theory & Method & Samples & $\begin{array}{c}\text { Smart Watch } \\
\text { External Factors }\end{array}$ & Study Type \\
\hline [17] & South Korea & TAM & Survey & $\begin{array}{l}\text { Participants } \\
\text { who owns } \\
\text { smartwatch }\end{array}$ & $\begin{array}{l}\text { Availability } \\
\text { Mobility }\end{array}$ & Adoption \\
\hline [20] & Malaysia & TAM & $\begin{array}{l}\text { Paper-based } \\
\text { Survey }\end{array}$ & $\begin{array}{l}\text { University } \\
\text { Students }\end{array}$ & $\begin{array}{l}\text { Visibility } \\
\text { Attitude }\end{array}$ & Adoption \\
\hline [18] & Korea & $\begin{array}{l}\text { Product-possessing } \\
\text { innovativeness } \\
\text { (PPI) and } \\
\text { information- } \\
\text { possessing } \\
\text { innovativeness } \\
\text { (IPI). }\end{array}$ & Survey & $\begin{array}{l}\text { University } \\
\text { Students }\end{array}$ & $\begin{array}{c}\text { relative advantage, } \\
\text { social image, } \\
\text { aesthetics, and } \\
\text { novelty }\end{array}$ & Adoption \\
\hline [19] & Taiwan & $\begin{array}{c}\text { Task-Technology } \\
\text { Fit, Innovation } \\
\text { Diffusion }\end{array}$ & $\begin{array}{l}\text { an online } \\
\text { survey }\end{array}$ & $\begin{array}{l}\text { University } \\
\text { Students }\end{array}$ & $\begin{array}{l}\text { Relative advantage } \\
\text { Complexity } \\
\text { Design aesthetics }\end{array}$ & Adoption \\
\hline [27] & Taiwan & $\begin{array}{l}\text { Senior Technology } \\
\text { Acceptance Model }\end{array}$ & Interview & $\begin{array}{l}\text { Adults and } \\
\text { their children }\end{array}$ & $\begin{array}{c}\text { Social Influence } \\
\text { Users Context }\end{array}$ & Adoption \\
\hline [28] & $\begin{array}{c}\text { France, } \\
\text { Thailand and } \\
\text { China }\end{array}$ & TAM & Survey & $\begin{array}{l}\text { University } \\
\text { Students }\end{array}$ & $\begin{array}{c}\text { Trust } \\
\text { Availability } \\
\text { Mobility }\end{array}$ & Adoption \\
\hline [29] & Turkey & $\begin{array}{l}\text { SAW-ARAS } \\
\text { approach in the } \\
\text { hesitant fuzzy } \\
\text { environment, }\end{array}$ & Survey & Research paper & $\mathrm{N} / \mathrm{A}$ & $\begin{array}{c}\text { Papers on } \\
\text { Acceptance } \\
\text { and Adoption }\end{array}$ \\
\hline [30] & $\begin{array}{l}\text { Developed } \\
\text { Countries: } \\
\text { UK, USA, } \\
\text { Germany, and } \\
\text { France }\end{array}$ & TAM & Survey & Consumers & $\begin{array}{c}\text { Perceived } \\
\text { Connectivity } \\
\text { Age and } \\
\text { gender-differences }\end{array}$ & Acceptance \\
\hline [31] & South Korea & TAM & Survey & $\begin{array}{l}\text { Hongik } \\
\text { University } \\
\text { Students }\end{array}$ & $\begin{array}{l}\text { Motivation } \\
\text { Innovative } \\
\text { Resistance }\end{array}$ & Acceptance \\
\hline [21] & $\begin{array}{c}\text { Not } \\
\text { Applicable }\end{array}$ & TAM & Online Survey & $\begin{array}{l}\text { Smart Wearable } \\
\text { devices users }\end{array}$ & $\begin{array}{c}\text { Satisfaction, } \\
\text { enjoyment, } \\
\text { usefulness, flow } \\
\text { state, and cost. }\end{array}$ & Acceptance \\
\hline
\end{tabular}


Table 1. Cont.

\begin{tabular}{|c|c|c|c|c|c|c|}
\hline Author(s) & $\begin{array}{l}\text { Country or } \\
\text { Place }\end{array}$ & Theory & Method & Samples & $\begin{array}{c}\text { Smart Watch } \\
\text { External Factors }\end{array}$ & Study Type \\
\hline [22] & Arab World & TAM \& TBP & Online Survey & Students & Mobility and Trust & Acceptance \\
\hline$[32]$ & India & UTAUT2 & Survey & Consumers & $\begin{array}{l}\text { Innovativeness } \\
\text { Self-efficacy, Social } \\
\text { media influence, } \\
\text { aesthetics }\end{array}$ & Adoption \\
\hline [33] & South Korea & IDT \& TAM & Online-Survey & $\begin{array}{l}\text { Company } \\
\text { Workers }\end{array}$ & $\mathrm{N} / \mathrm{A}$ & Adoption \\
\hline$[34]$ & Asia & TAM & Survey & $\begin{array}{l}\text { East Asian } \\
\text { university }\end{array}$ & $\begin{array}{l}\text { Subcultural appeal } \\
\text { Attractiveness }\end{array}$ & Adoption \\
\hline [35] & Taiwan & TAM & Survey & $\begin{array}{l}\text { Students at } \\
\text { University }\end{array}$ & $\begin{array}{l}\text { Innovativeness } \\
\text { Experiential Value }\end{array}$ & $\begin{array}{l}\text { Continuous } \\
\text { intention }\end{array}$ \\
\hline
\end{tabular}

Based on the previous table, it seems that studies on the adoption of smartwatches used one unified tool, which is the questionnaire in which TAM is considered a concrete part of the model [33-35]. The only exception to the previous assumption is a study carried out by [32] where UTAUT2 as an extended model is added. The TAM model seems to affect the adoption in two different ways. The first one is related to the perceived usefulness, which is a crucial element that may be affected by various extended factors. The other is perceived ease of use, which is a decisive element that can be connected to fashion and innovativeness as an external factor; thus, they affect the adoption of smartwatches significantly [33-35].

\section{The Adopted Model and Hypotheses Development}

The current study assumes that content richness and personal innovativeness have a close relationship to TAM constructs of perceived usefulness and perceived ease of use. The TAM model has been extended to include the external factors of content richness and innovativeness to measure the final goal of SW adoption. The following sections provide more insight into this issue.

\subsection{Content Richness}

Content richness refers to learning resources that can embrace three dimensions, namely, relevance, timeliness and adequacy [36]. One of the criteria within content richness is sufficiency, which is related to a variety of information that is provided to the users. On the other hand, timeliness or the so-called 'currentness' is defined as the extent to which up-to-date information can be provided to the users [37,38]. It has been argued that information that is out of date is not useful. Hence, information that can be obtained from technology can be evaluated as time-critical [39]. Relevance refers to the relation between the type of obtained information and users' needs [40]. Studies [41,42] have focused on the relationship between content richness and perceived usefulness. Technology can be classified as having high quality or content whenever it is proven to be useful to users. Based on that, the following hypothesis is formed:

Hypothesis 1 (H1). Sufficiency (SUF) has a positive effect on the perceived usefulness of SW (PU).

Hypothesis 2 (H2). Timeless (TIM) has a positive effect on the perceived usefulness of SW (PU).

Hypothesis 3 (H3). Relevance (REL) has a positive effect on the perceived usefulness of SW (PU). 


\subsection{Personal Innovativeness}

Personal innovativeness has a direct connection with users' readiness to use new technology as soon as it is invented and becomes available [43]. Personal innovativeness is believed to have a close relationship with confidence and perception of technology. Users with a high degree of personal innovativeness have a greater level of confidence in their abilities. Similarly, users with a high perception of technology are more likely to have a higher level of personal innovativeness [44,45].

Based on the previous assumption, users take certain choices concerning the adoption of technology. Personal innovativeness is one of the choices that a user can make which can consequently affect their adoption of technology. The effectiveness of personal innovativeness seems to be positive, hence enhancing directly the users' acceptance or adoption of technology. This can be linked with TAM theory, where ease of use and perceived usefulness are supposed to have a positive effect on personal innovativeness [46-49]. Hence, the following hypotheses are formulated:

Hypothesis 4 (H4). Personal innovativeness (PER) has a positive effect on the perceived usefulness of $S W(P U)$.

Hypothesis 5 (H5). Personal innovativeness (PER) has a positive effect on the perceived ease of use of SW (PEOU).

\subsection{TAM Model}

TAM has been implemented widely in previous studies to predict the adoption, acceptance, and intention to use technology in different fields [50,51]. To put it more specifically, this study has focused on two constructs of TAM that are supposed to have a direct relation to the adoption of the smartwatch as wearable technology. The first variable is the perceived usefulness, which can be best explained as users' attitude towards the degree of usefulness that the technology may have. The other variable is used to measure how far the technology is free of effort from users' perspectives [15,52]. To apply the previous assumptions, the following hypotheses are proposed:

Hypothesis 6 (H6). Perceived usefulness (PU) positively affects the adoption of SW (ASW).

Hypothesis 7 (H7). Perceived ease of use (PEOU) positively affects the adoption of SW (ASW).

The proposed research models rely on these hypotheses, as shown in Figure 1.

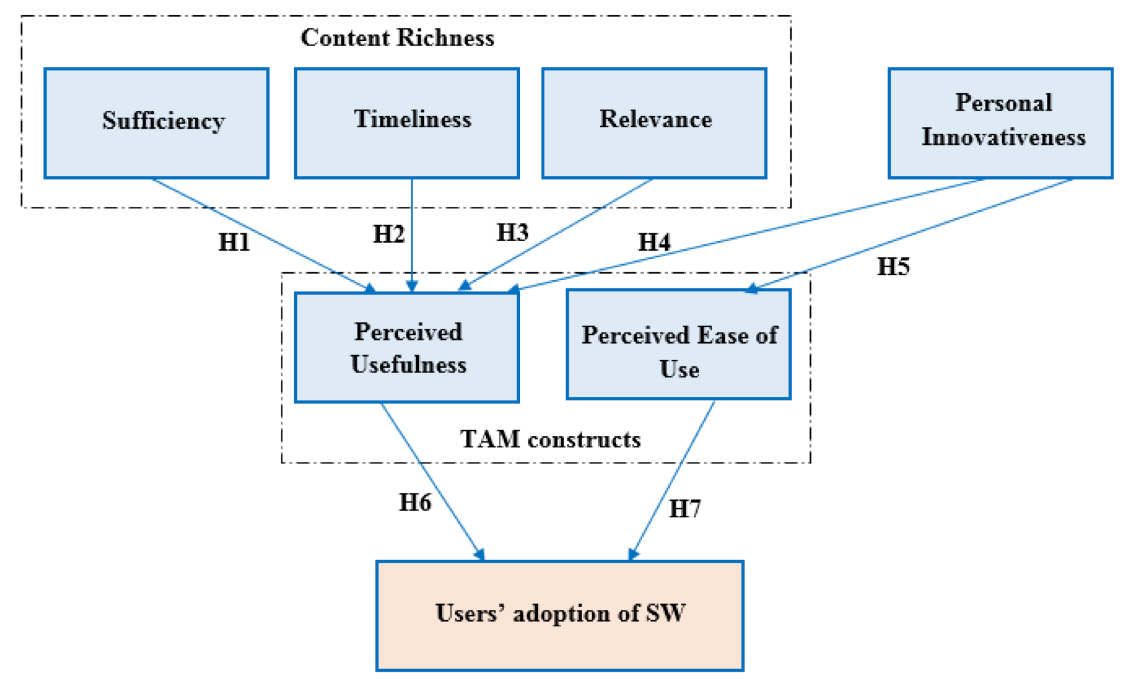

Figure 1. Research Model. 


\section{Research Methodology}

A cross-sectional design was used in this descriptive-analytical study as a deductive strategy. The data collection instrument used in the study was an online questionnaire that used a self-administrated strategy to collect data from health care workers in the United Arab Emirates (UAE), specifically the Emirate of Dubai. This examination study was led at a healthcare clinic in Dubai whereby seven primary healthcare clinics and five hospitals participated in the study; the study had a duration of one month from 15 December 2020 to 15 January 2021. The health care workers were provided with the questionnaire link by making use of official emails and social media platforms like WhatsApp. For data collection, various healthcare providers like the administration staff (registration, quality, receptionists, and administrative supports) and clinical staff (physicians, nurses, and allied health professionals) working at the selected hospitals and healthcare centers were approached since this personnel could contribute essential information about healthcare provision within healthcare facilities as suggested by [53].

Moreover, in the context of an empirical study pertaining to healthcare service management, various researchers opted for the target population to serve as a unit of analysis for the current research [54-57]. As per [57], those individuals had a satisfactory level of knowledge regarding various organizational practices in the context of healthcare management as well as about the degree of service quality and customer satisfaction offered by their respective organizations. In this investigation, a non-probability sampling technique was used by implementing a convenience sampling strategy. Generally, the fundamental explanation behind this choice was the strict policies in healthcare organizations in Dubai regarding the protection of staff information and ensuring the security and privacy of such information. Moreover, the policies of the participating hospitals and primary clinics regarding access to sampling also led to the selection of this technique. Besides this, ref. [58] demonstrated that convenience sampling is the most time-friendly and budget-friendly sampling technique and allows the accessing of huge samples.

\subsection{Data Collection}

In this study, out of 400 questionnaires distributed randomly, 75 questionnaires were rejected due to missing values. The correctly completed and usable 325 questionnaires accounted for the response rate of 81 percent. These 325 questionnaires were then analyzed. The correct 325 questionnaires were collected according to the sample size level mentioned in [59]; the estimated sampling size of a 1500 population is 306 respondents. In the following case, the structural equation modeling is allowed to be used according to [60] as a sample size of 325 seems to be far bigger than the required sample size. The model is used to verify the hypotheses. It is essential to consider that the Hypotheses are developed on the existing theories, but they are often structured in correspondence to the framework of smartwatch adoption. To evaluate the measurement model, structural equation modeling (SEM) is applied to it and consequently it is handled by the final path model.

\subsection{Students' Personal Information/Demographic Data}

Table 2 shows the facts obtained by the assessment of personal/demographic data, which are as follows: The proportion of the females and males were $62 \%$ and $38 \%$, respectively. Eleven percent of respondents were aged from 18 to 29 years whereas $89 \%$ of respondents are aged above 29 years. Many of the respondents belonged to a well-educated background and most of them had completed university degrees. Of the respondents, $73 \%$, $14 \%, 12 \%$ had a bachelor's, master's, and doctoral degree respectively, whereas the remaining respondents were diploma qualified. The purposive sampling approach was utilized according to [61] because the respondents were eager to voluntarily participate in the study. The study sample involved respondents of different ages, belonging to various sectors, with several different experiences of different educational levels. For the measurement of demographic data, IBM SPSS Statistics ver. 23 was used. Table 2 represents the complete demographic data of the respondents. 
Table 2. Demographic data of the respondents.

\begin{tabular}{|c|c|c|c|}
\hline Criterion & Factor & Frequency & Percentage \\
\hline \multirow{2}{*}{ Gender } & Female & 201 & $62 \%$ \\
\hline & Male & 124 & $38 \%$ \\
\hline \multirow{4}{*}{ Age } & Between 18 to 29 & 36 & $11 \%$ \\
\hline & Between 30 to 39 & 211 & $65 \%$ \\
\hline & Between 40 to 49 & 72 & $22 \%$ \\
\hline & Between 50 to 59 & 6 & $2 \%$ \\
\hline \multirow{4}{*}{$\begin{array}{c}\text { Education } \\
\text { qualification }\end{array}$} & Diploma & 3 & $1 \%$ \\
\hline & Bachelor & 236 & $73 \%$ \\
\hline & Master & 48 & $14 \%$ \\
\hline & Doctorate & 38 & $12 \%$ \\
\hline \multirow{5}{*}{ Experience } & $1-5$ & 26 & $8 \%$ \\
\hline & $5-10$ & 88 & $27 \%$ \\
\hline & $10-15$ & 156 & $48 \%$ \\
\hline & $15-20$ & 25 & $8 \%$ \\
\hline & $20+$ & 30 & $9 \%$ \\
\hline \multirow{2}{*}{ Type of Sector } & Federal/Government & 310 & $95 \%$ \\
\hline & Private & 15 & $5 \%$ \\
\hline
\end{tabular}

\subsection{Study Instrument}

The survey instrument was developed and added to this research to verify the hypothesis. The survey includes 20 items to measure the four constructs found in the questionnaire. To increase the applicability of the research, the questions from the previous studies were revised and redesigned before inclusion in the questionnaire. The sources of the used constructs are displayed in Table 3.

Table 3. Constructs and their sources.

\begin{tabular}{|c|c|c|c|}
\hline Constructs & Items & Instrument & Source \\
\hline \multirow{2}{*}{ Adoption of SW } & ASW1 & Using SW is recommended within medical environment. & \multirow{2}{*}[52,62,63]{} \\
\hline & ASW2 & Using SW with my patients and peers develops helps me in my career. & \\
\hline \multirow{3}{*}{ Perceived Ease of Use } & PEOU1 & I think that SW is easy to use among doctors and patients. & \multirow{3}{*}[64,65]{} \\
\hline & PEOU2 & I think SW can replace other technology because it is easy to use. & \\
\hline & PEOU3 & I think SW is a complicated device and need mental effort. & \\
\hline \multirow{4}{*}{ Perceived Usefulness } & PU1 & I think that SW helps in developing my technical abilities. & \multirow{4}{*}[64,65]{} \\
\hline & PU2 & I think that SW improves my desire to get new information regularly. & \\
\hline & PU3 & $\begin{array}{c}\text { I think that SW is a good source of medical information for both doctors } \\
\text { and patients. }\end{array}$ & \\
\hline & PU4 & $\begin{array}{c}\text { I think that using SW makes it difficult to get an immediate type } \\
\text { of information }\end{array}$ & \\
\hline \multirow{3}{*}{ Relevance } & REL1 & SW offers sufficient content that I need. & \multirow{3}{*}{ [37] } \\
\hline & REL2 & SW has very useful information for me as a doctor or a patient. & \\
\hline & REL3 & SW is not a source of sufficient content that exactly satisfies my needs. & \\
\hline
\end{tabular}


Table 3. Cont.

\begin{tabular}{|c|c|c|c|}
\hline Constructs & Items & Instrument & Source \\
\hline \multirow{3}{*}{ Sufficiency } & SUF1 & SW has sufficient medical information. & \multirow{3}{*}{ [37] } \\
\hline & SUF2 & SW has provided me with satisfactory information whenever I need it. & \\
\hline & SUF3 & $\mathrm{SW}$ is unable to provide me with the information I need. & \\
\hline \multirow{2}{*}{ Timeliness } & TIM1 & SW has up-to-date medical information that I need. & \multirow{2}{*}{ [37] } \\
\hline & TIM2 & SW is unable to support me with up-to-date-information. & \\
\hline \multirow{3}{*}{ Personal Innovativeness } & PER1 & Whenever there is new technology, I am ready to use it. & \multirow{3}{*}{ [66] } \\
\hline & PER2 & I am the first one to use new technology among my group of doctors & \\
\hline & PER3 & I am usually hesitant to use new technology. & \\
\hline
\end{tabular}

\subsection{Pilot Study of the Questionnaire}

To calculate the reliability of the questionnaire items a pilot study was performed. The pilot study involved 40 participants selected randomly from the participating population. The sample size was $10 \%$ of the total sample size, which is equivalent to 40 participates out of 400 as per the research standards. To evaluate the results of the pilot study, Cronbach's alpha test for internal reliability was utilized through IBM SPSS Statistics ver. 23, which implied the adequacy of measurement items. A reliability coefficient of 0.70 is acceptable [67] as evident from social science research studies. Table 4 displays the values of Cronbach alpha corresponding to the given seven measurement scales.

Table 4. Cronbach's alpha values for the pilot study (Cronbach's Alpha $\geq 0.70$ ).

\begin{tabular}{cc}
\hline Constructs & Cronbach's Alpha \\
\hline ASW & 0.883 \\
\hline PEOU & 0.801 \\
\hline PU & 0.848 \\
\hline CONT & 0.707 \\
\hline REL & 0.765 \\
\hline TIM & 0.869 \\
\hline SUF & 0.831 \\
\hline PER &
\end{tabular}

Note: ASW, Adoption of SW; PEOU, Perceived Ease of Use; PU, Perceived Usefulness; CONR, Content Richness (REL, Relevance; TIM, Timeliness; SUF, Sufficiency); PER, Personal Innovativeness.

\subsection{Survey Structure}

The researcher circulated a questionnaire survey among the participants of the United Arab Emirates medical center (UAE) in the form of an online survey $(N=400)$. The Primary Health care sector participated in the following study. They are both well-known hospitals in the UAE. A questionnaire survey was developed and distributed among the participants [61]. This survey consists of the following sections:

- The foremost section contains the personal data of the participants.

- The next section contains the two items of basic questions about the adoption of smartwatches.

- The third section contains eighteen items related to Perceived Ease of Use, Perceived Usefulness, Content Richness (Relevance, Timeliness, and Sufficiency), and Personal Innovativeness. 
For the measurement of (20 items) in the questionnaire, a five-point Likert Scale was used that is based on the scales of strongly agreed (5), agree (4), neutral (3), disagree (2), and strongly disagree (1).

\section{Findings and Discussion}

\subsection{Data Analysis}

In the following research, the partial least squares-structural equation modeling (PLSSEM) via SmartPLS V.3.2.7 was used for the data analysis [68]. The opted model used for the analysis of collected data was based on the two-layered assessment methodology consisting of the measurement model and the structural model [69]. The factors for choosing the PLS-SEM in this research are, foremost, that PLS-SEM is known to be the better option for research that seeks to establish the current theory [70]. Second, PLS-SEM supported the exploratory research with complex models in a better way [71]. Third, instead of breaking the model into bits, the PLS-SEM analyzes it as a whole unit [72]. Fourth, using the PLS-SEM yields more precise results due to its simultaneous analysis for measurement and structural model [73].

\subsection{Convergent Validity}

In [69], to assess the measurement model, it was proposed to determine construct reliability (consisting of Cronbach's alpha and composite reliability), as well as validity (consisting of convergent and discriminant validity). In the context of the measurement of construct reliability, Table 5 shows that the values of Cronbach's alpha lie between 0.741 and 0.899 , which is quite high from the suggested threshold value of 0.7 [74]. The following table also depicts that the value of composite reliability (CR) lies within 0.705 and 0.903 , which is more than the suggested value of 0.7 [75]. Construct reliability is verified through these results, indicating the free-of-error constructs.

Table 5. Convergent validity results which assure acceptable values (Factor loading, Cronbach's Alpha, composite reliability $\geq 0.70 \&$ AVE $>0.5$ ).

\begin{tabular}{|c|c|c|c|c|c|}
\hline Constructs & Items & $\begin{array}{c}\text { Factor } \\
\text { Loading }\end{array}$ & $\begin{array}{c}\text { Cronbach's } \\
\text { Alpha }\end{array}$ & CR & AVE \\
\hline \multirow{2}{*}{ Adoption of SW } & ASW1 & 0.857 & \multirow{2}{*}{0.848} & \multirow{2}{*}{0.859} & \multirow{2}{*}{0.658} \\
\hline & ASW2 & 0.851 & & & \\
\hline \multirow{3}{*}{ Perceived ease of use } & PEOU1 & 0.849 & \multirow{3}{*}{0.899} & \multirow{3}{*}{0.833} & \multirow{3}{*}{0.688} \\
\hline & PEOU2 & 0.800 & & & \\
\hline & PEOU3 & 0.786 & & & \\
\hline \multirow{4}{*}{ Perceived usefulness } & PU1 & 0.881 & \multirow{4}{*}{0.833} & \multirow{4}{*}{0.903} & \multirow{4}{*}{0.779} \\
\hline & PU2 & 0.881 & & & \\
\hline & PU3 & 0.844 & & & \\
\hline & PU4 & 0.859 & & & \\
\hline \multirow{3}{*}{ Relevance } & REL1 & 0.843 & \multirow{3}{*}{0.812} & \multirow{3}{*}{0.789} & \multirow{3}{*}{0.703} \\
\hline & REL2 & 0.859 & & & \\
\hline & REL3 & 0.806 & & & \\
\hline \multirow{2}{*}{ Timeliness } & TIM1 & 0.794 & \multirow{2}{*}{0.840} & \multirow{2}{*}{0.828} & \multirow{2}{*}{0.799} \\
\hline & TIM1 & 0.822 & & & \\
\hline \multirow{3}{*}{ Sufficiency } & SUF1 & 0.835 & \multirow{3}{*}{0.820} & \multirow{3}{*}{0.796} & \multirow{3}{*}{0.760} \\
\hline & SUF2 & 0.874 & & & \\
\hline & SUF3 & 0.824 & & & \\
\hline \multirow{3}{*}{$\begin{array}{c}\text { Personal } \\
\text { Innovativeness }\end{array}$} & PER1 & 0.897 & \multirow{3}{*}{0.876} & \multirow{3}{*}{0.861} & \multirow{3}{*}{0.782} \\
\hline & PER1 & 0.821 & & & \\
\hline & PER1 & 0.847 & & & \\
\hline
\end{tabular}


The factor loading and average variance extracted (AVE) must be determined to measure convergent validity [69]. Table 5 indicates that the values of factor loadings are seemingly more than the standard value of 0.7 . Table 5 also displays the AVE values which are found to be from 0.609 to 0.799 , which cross the standard threshold value of 0.5 . With the following findings, convergent validity has been properly satisfied for each of the mentioned constructs.

\subsection{Discriminant Validity}

The following criteria need to be taken into consideration: the Fornell-Larker criterion, and the Heterotrait-Monotrait ratio (HTMT) for the measurement of discriminant validity [69]. Table 6 shows that the value of the square root of each value of AVE is more than their correlation constructs; thus indicating the verification of the Fornell-Larker criterion [76].

Table 6. Fornell-Larcker Scale.

\begin{tabular}{cccccccc}
\hline & ASW & PEOU & PU & REL & TIM & SUF & PER \\
\hline ASW & $\mathbf{0 . 8 4 4}$ & & & & & & \\
\hline PEOU & 0.203 & $\mathbf{0 . 8 4 9}$ & & & & & \\
\hline PU & 0.124 & 0.668 & $\mathbf{0 . 8 2 9}$ & & & & \\
\hline REL & 0.205 & 0.288 & 0.330 & $\mathbf{0 . 8 5 3}$ & & & \\
\hline TIM & 0.207 & 0.278 & 0.526 & 0.890 & $\mathbf{0 . 8 3 6}$ & & \\
\hline SUF & 0.203 & 0.296 & 0.636 & 0.896 & 0.424 & $\mathbf{0 . 8 6 1}$ & \\
\hline PER & 0.200 & 0.281 & 0.652 & 0.895 & 0.523 & 0.419 & $\mathbf{0 . 8 2 9}$ \\
\hline
\end{tabular}

Note: ASW, Adoption of SW; PEOU, Perceived Ease of Use; PU, Perceived Usefulness; CONR, Content Richness (REL, Relevance; TIM, Timeliness; SUF, Sufficiency); PER, Personal Innovativeness.

The values of the HTMT ratio mentioned in Table 7 for all constructs remained below the 0.85 threshold value [77], explicitly indicating affirmation of the HTMT ratio. Given the following results, discriminant validity is also established. Through the analysis of the following results, it is now evident that no errors are found in reliability and validity during the assessment of the measurement model. This gives a clear signal for collected data to be utilized for the assessment of the structural model.

Table 7. Heterotrait-Monotrait Ratio (HTMT).

\begin{tabular}{cccccccc}
\hline & ASW & PEOU & PU & REL & TIM & SUF & PER \\
\hline ASW & & & & & & \\
\hline PEOU & 0.445 & & & & & \\
\hline PU & 0.266 & 0.368 & & & & \\
\hline REL & 0.449 & 0.427 & 0.359 & & & \\
\hline TIM & 0.453 & 0.523 & 0.363 & 0.505 & & \\
\hline SUF & 0.477 & 0.602 & 0.399 & 0.591 & 0.452 & \\
\hline PER & 0.526 & 0.521 & 0.448 & 0.600 & 0.498 & 0.510 \\
\hline
\end{tabular}

Note: ASW, Adoption of SW; PEOU, Perceived Ease of Use; PU, Perceived Usefulness; CONR, Content Richness

(REL, Relevance; TIM, Timeliness; SUF, Sufficiency); PER, Personal Innovativeness.

\subsection{Hypotheses Testing Using PLS-SEM}

After the assessment of the measurement model, the next in line is the structural model [78-90]. This involves the evaluation of coefficient of determination $\left(\mathrm{R}^{2}\right)$, path coefficients through bootstrapping which is the long process involving 5000 re-samples [81,86,91-93]. Table 8 provides the path coefficients, $t$-values, and $p$-values for all hypotheses concerning 
the path analysis. All of the researchers have supported every hypothesis. Interpretation of data shows that the hypotheses ( $\mathrm{H} 1, \mathrm{H} 2, \mathrm{H} 3, \mathrm{H} 4, \mathrm{H} 5, \mathrm{H} 6$, and $\mathrm{H} 7)$ have been supported by empirical data.

Table 8. Hypotheses-testing of the research model (significant at ${ }^{* *} p \leq 0.01,{ }^{*} p<0.05$ ).

\begin{tabular}{ccccccc}
\hline H & Relationship & Path & $t$-Value & $p$-Value & Direction & Decision \\
\hline H1 & SUF-> PU & 0.515 & 20.349 & 0.002 & Positive & Supported $^{* *}$ \\
\hline H2 & TIM-> PU & 0.382 & 18.238 & 0.000 & Positive & Supported $^{* *}$ \\
\hline H3 & REL-> PU & 0.478 & 18.608 & 0.000 & Positive & Supported $^{* *}$ \\
\hline H4 & PER-> PU & 0.281 & 4.125 & 0.038 & Positive & Supported $^{*}$ \\
\hline H5 & $\begin{array}{c}\text { PER-> } \\
\text { PEOU }\end{array}$ & 0.329 & 16.288 & 0.000 & Positive & Supported $^{* *}$ \\
\hline H6 & PU-> ASW & 0.668 & 12.433 & 0.004 & Positive & Supported \\
\hline H7 & $\begin{array}{c}\text { PEOU-> } \\
\text { ASW }\end{array}$ & 0.420 & 3.275 & 0.043 & Positive & Supported * \\
\hline
\end{tabular}

Note: ASW, Adoption of SW; PEOU, Perceived Ease of Use; PU, Perceived Usefulness; CONR, Content Richness (REL, Relevance; TIM, Timeliness; SUF, Sufficiency); PER, Personal Innovativeness.

The testing of the structural model is usually done based on the measurement of coefficient of determination ( $R^{2}$ value) [71]. The coefficient is expressed as the squared correlation between actual and predicted values of the particular endogenous construct, and the main aim of this coefficient is to measure the predictive accuracy of the model [94,95]. The coefficient indicates the cumulative influence of the exogenous latent variables over an endogenous latent variable. As the coefficient is the squared correlation between the actual values of the variables and the predicted values of variables, it introduces further the sense of variance degree in the endogenous constructs. The value is considered to be high if it exceeds 0.67 , which indicates that the values ranging from 0.33 to 0.67 are direct ones and the value between 0.19 to 0.33 are considered weak values. The value is termed inadmissible if it is smaller than 0.19 according to [96]. As seen in Table 9 and Figure 2, it is clear that the model had high predictive power, supporting very nearly $75.6 \%, 77.3 \%$, and $82.8 \%$ of the variance in the adoption of SW, perceived usefulness and perceived ease of use, respectively.

Table 9. $\mathrm{R}^{2}$ of the endogenous latent variables.

\begin{tabular}{ccc}
\hline Constructs & $\mathbf{R}^{\mathbf{2}}$ & Results \\
\hline ASW & 0.756 & High \\
\hline PEOU & 0.828 & High \\
\hline PU & 0.773 & High \\
\hline
\end{tabular}

Note: ASW, Adoption of SW; PEOU, Perceived Ease of Use; PU, Perceived Usefulness.

Sufficiency (SUF), Timeliness (TIM), Relevance (REL) and Personal Innovativeness (PER) have significant effects on Perceived Usefulness (PU) $(\beta=0.515, p<0.01),(\beta=0.382$, $p<0.001),(\beta=0.478, p<0.001)$, and $(\beta=0.281, p<0.05)$ respectively; hence $\mathrm{H} 1, \mathrm{H} 2, \mathrm{H} 3$, and H4 are supported. The relationship between Personal Innovativeness (PER) and Perceived Ease of Use (PEOU) $(\beta=0.329, p<0.001)$ is statistically significant, so hypothesis H5 is generally supported. Perceived Usefulness (PU) and Perceived Ease of Use (PEOU) have significant effects on Adoption of Smart Watch (ASW) $(\beta=0.668, p<0.01)$, and $(\beta=0.420$, $p<0.05)$, respectively; therefore, $\mathrm{H} 6$ and $\mathrm{H} 7$ are supported. A summary of the hypotheses testing results is shown in Table 8. 


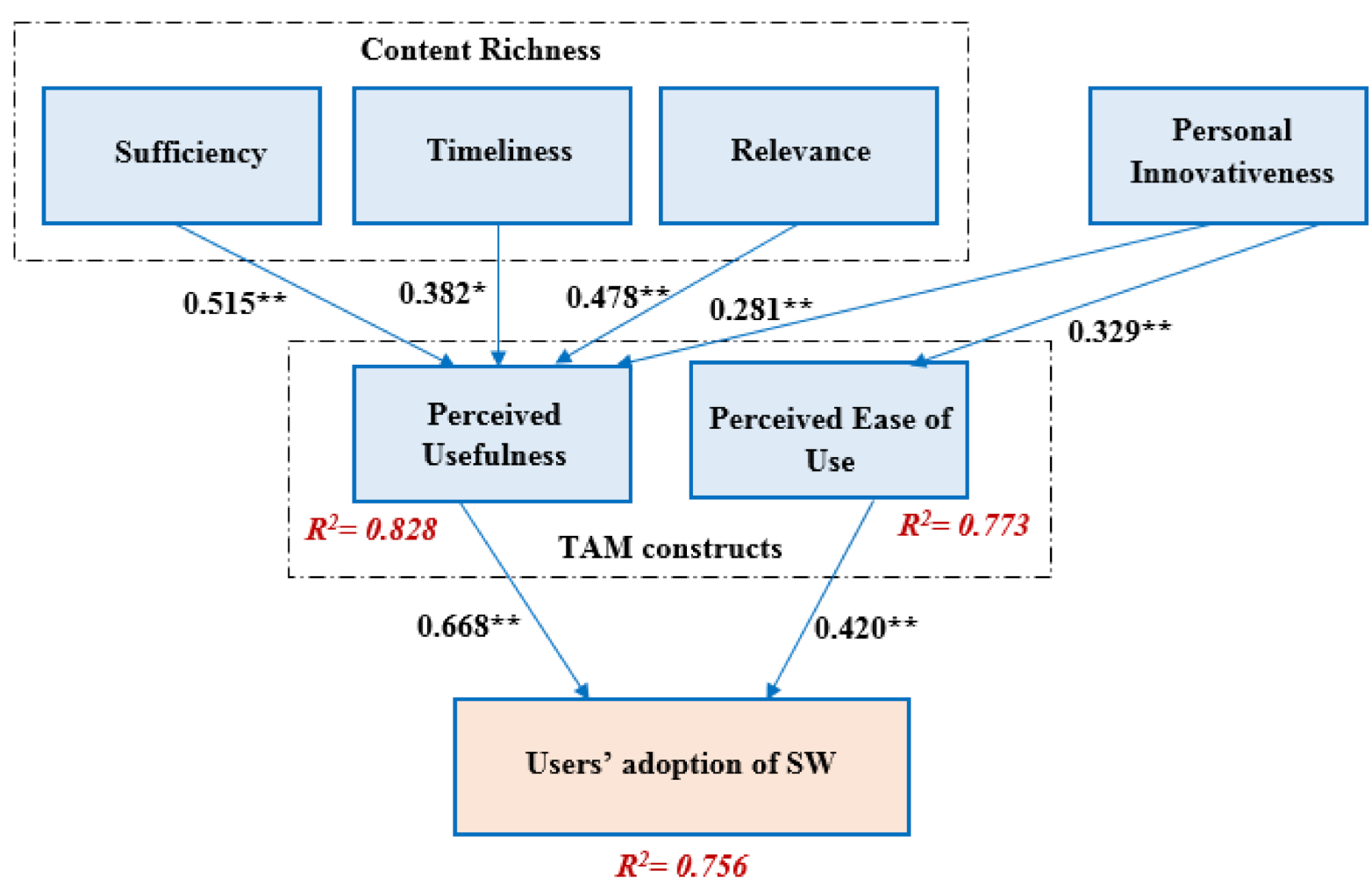

Figure 2. Path coefficient of the model (significant at ${ }^{* *} p \leq 0.01,{ }^{*} p<0.05$ ).

\section{Discussion}

The current study empirically examines the effectiveness of smartwatch adoption in the medical field. To validate the usage of the smartwatch, an integrated model that integrated TAM constructs with external factors was adopted. The external factors include personal innovativeness and content richness. Specifically, this study reveals that content richness can positively affect smartwatch adoption and can lead to a greater degree of adoption by taking into consideration the three crucial factors of timeliness, relevancy and sufficiency. In addition, it seems that content richness positively and significantly affects the perceived usefulness; therefore, it urges more users to adopt smartwatches. The current study seems to be in line with previous studies where perceived ease of use and perceived usefulness are affected by quality content $[35,97,98]$. The content richness seems to work as an external factor in previous studies and significantly influences perceived usefulness in studies of acceptance [35,99]. Personal innovativeness has a close relationship with personal characteristics where users with a high degree of personal innovativeness seem to be more enthusiastic to use the technology. Based on the results of the study, it seems that personal effectiveness prominently affects the perceived ease of use and to a lesser extent the perceived usefulness. The current result seems to agree with results that are presented by many previous researchers such as $[100,101]$ who stated that personal innovativeness' impact on technology adoption is vital and decisive. It has a close relationship with personality traits. Moreover, it seems that innovativeness has a close relationship with enjoyment. Whenever users feel that the level of enjoyment is high, their personal innovativeness will be high as well [102].

The two TAM variables have proven to have a direct and significant effect on the adoption of the smartwatch. The results have shown that perceived ease of use and perceived usefulness significantly affect adoption. They assume that whenever technology is described as free of effort or useful, it will be in high demand by different users in different fields including academic and non-academic [103,104]. Within the medical field, previous research papers agree with the current results in that they conclude that doctors, nurses and patients are willing to use technology under the condition of being easy to 
use and useful $[105,106]$. Apparently, the main obtained results confirmed the proposed hypotheses where SW as wearable technology is highly accepted among users in the medical field. In general, the acceptance of SW is supported positively. The efficiency of the perceived ease of use and perceived usefulness pave the way to the fact that SW future updates will be highly preferred by its users. Hence, the TAM model with its two constructs helped to validate our hypotheses due to the high acceptance of these two constructs in the obtained results. The two other factors of content richness and personal innovativeness contribute to the acceptance of SW differently. The content richness is related to features of SW itself whereas the personal innovativeness is related to the psychological factor to the users themselves. The fact that the suggested hypotheses have been supported implies that these two factors contribute significantly to the acceptance. The relatedness of information and the latest information are part of content richness. Both of them have been supported positively due to their high impact on users within the medical field. The fact that all users in the medical field need the recent type of information contributes significantly to the acceptance of SW. Similarly, the psychological effect of personal innovativeness, where psychological readiness to accept technology is the crucial factor, is highly supported. The personal psychological readiness and SW specific features increased the level of SW acceptance. Thus, SW has gained a wide reputation among doctors and patients.

\subsection{Practical Implication in the Medical Field}

This study provides a noteworthy contribution for wearable technology developers to develop new wearable technology that can serve the medical field in the future. Our results indicate that any investment in wearable technology should serve both users' specific needs and the medical environment's general requirements. Awareness of how the coming invented wearable technology can serve doctors' needs is a must, thus, developers of technology should favorably add features that serve doctors' usage and enhance their willingness to use the technology.

Developers of technology have to be aware of the availability of certain features in a specific time and with specific functions. These specific functions, that a smartwatch may have, affect users' decisions and technology adoption $[107,108]$. In this study, the significance of getting acquainted with specific tasks (i.e., getting correct information at the right timing) may lead to the fact that users start depending on the wearable technology more frequently. Doctors and patients have increasingly been affected by technology adoption whenever certain features are updated and become more relevant to their needs.

Whenever the functions that are provided by wearable technology fit within the medial field properly, the wearable technology managers will be ready to grasp the needs of the individual and adjust the features of the technology to fit in more effectively. Then the degree of compatibility between the individual's needs and wearable technology will serve the long-term goal behind using it.

\subsection{Managerial Implication in the Medical Field}

Firstly, recommendations are directed to the administration of hospitals. They may use it to enhance the use of wearable technology in different parts since smart wearable technology may have a supportive role in developing other related applications. Secondly, recommendations are directed to patients who can use different smart wearable technology via phone-based applications. Thirdly, the findings reveal significant implications for doctors and patients due to the fact that wearable technology has been identified as a crucial tool in the medical field. It implies that wearable technology has to be developed by adding new features or upgrading current features that can be of great benefit to practitioners, doctors, and patients $[109,110]$.

The results offer guidance for practitioners, doctors and physicians to use wearable technology for different medical purposes effectively. Specifically speaking, it is predictable that the external factor of content-richness may urge the user to adopt the technology, 
hence, doctors should be aware of these features and make a wise usage. They should urge patients to make use of them as well.

Well-designed wearable technology performance is accompanied by a variety of medical-specific features such as carbohydrate, blood glucose, and insulin unit entry, viewing all the previously required recorded and recording of the required physical activities $[13,14]$. Based on previous studies, it seems that whenever these features are characterized as user-friendly, users will be eager to use technology in the future [111]. Therefore, doctors and hospital managers are asked to reconsider the most significant medical features to upgrade them or even create new features that will fit perfectly with users' medical needs for the betterment of medical wearable technology.

\subsection{Limitations of the Study}

In this research, there were some prominent limitations, which are as follows: The study was only conducted in the five hospitals and seven primary healthcare centers in $\mathrm{UAE}$ and that is the key limitation, as a sample of only five hospitals and seven primary healthcare centers is not sufficient to study the influence of Smart Watch adoption. The applicability of the study could have been greater if more hospitals of the UAE had participated in it. Further research and objective study of the SmartWatch may prove helpful in the deduction of the variables affecting a real Smart Watch. In this research, only 325 participates took part which is also a limitation. Data was collected through a survey questionnaire system, according to [112]. There was a need for an improved instrument, sampling method, and participation of more institutes from other regions, such as the Arab Gulf region, including countries like KSA, Kuwait, and Bahrain, for enhanced and more acceptable results. Furthermore, more students will be asked to engage in the research. For better results, interviews and focus group sessions will be organized. In specific Arab hospitals that have participated in the research will be prepared to incorporate a SmartWatch.

A few limitations were noted during this research that shall be kept in mind in the future while carrying out new ones. Since only the frontline healthcare workers of were taken into account, it could play negatively in respect of generalizability of this research; but the participation of other healthcare providers was also not feasible for this study. Due to time and cost limitations, the only governmental sector was approached for the collection of data leading to the representation of only a specific service culture. Since the data were only collected from a particular service sector, the generalization aspect must be dented when considering the other service industries. In addition, although this investigation has received a cross-sectional design utilizing the survey questionnaire to gather the data, and the data collection length was short, it ought to be noted that a longitudinal research design could be utilized and a more extended oversight should be possible by different investigations to have insight into COVID-19's mental health effects. Ultimately, the survey questionnaire was used as a primary instrument for the collection of required data in this research. In this way, it is prescribed to utilize other data collection means or utilizing data triangulation techniques, for example, observations and interviews for healthcare workers to have a more comprehensive knowledge of the impacts of the pandemic.

\subsection{Future Work}

The current study has focused on specific external variables that may increase the visibility of smartwatches. Future work may modify the external variables based on the newly developed features and usages of smartwatches. Besides, the current study focuses on the TAM model with certain external factors, other researchers may focus on other models that may serve certain social and psychological factors. Furthermore, this study is limited to the medical field; other studies can include other academic and nonacademic environments. Finally, the role of gender difference has not been focused on in the current study, which paves the way for future studies to dig deep and illustrate the main gender differences. 
Author Contributions: Data curation, K.A.; Investigation, A.Q.A.; Methodology, S.S.; Project administration, A.A.; Resources, S.S.; Supervision, S.S.; Writing—original draft, R.S.A.-M. All authors have read and agreed to the published version of the manuscript.

Funding: This research received no external funding.

Data Availability Statement: The data presented in this study are available on request from the corresponding author.

Conflicts of Interest: The authors declare no conflict of interest.

\section{References}

1. Niknejad, N.; Ismail, W.B.; Mardani, A.; Liao, H.; Ghani, I. A comprehensive overview of smart wearables: The state of the art literature, recent advances, and future challenges. Eng. Appl. Artif. Intell. 2020, 90, 103529. [CrossRef]

2. Talukder, M.S.; Chiong, R.; Bao, Y.; Malik, B.H. Acceptance and use predictors of fitness wearable technology and intention to recommend. Ind. Manag. Data Syst. 2019, 119, 170-188. [CrossRef]

3. AlQudah, A.A.; Salloum, S.A.; Shaalan, K. The Role of Technology Acceptance in Healthcare to Mitigate COVID-19 Outbreak. Emerg. Technol. Dur. Era COVID-19 Pandemic 2021, 348, 223.

4. Al Mansoori, S.; Almansoori, A.; Alshamsi, M.; Salloum, S.A.; Shaalan, K. Suspicious Activity Detection of Twitter and Facebook using Sentimental Analysis. TEM J. 2020, 4, 1313-1319. [CrossRef]

5. Lyons, K. What can a dumb watch teach a smartwatch? Informing the design of smartwatches. In Proceedings of the 2015 ACM international symposium on wearable computers, Osaka, Japan, 9-11 September 2015; pp. 3-10.

6. Xu, C.; Pathak, P.H.; Mohapatra, P. Finger-writing with smartwatch: A case for finger and hand gesture recognition using smartwatch. In Proceedings of the 16th International Workshop on Mobile Computing Systems and Applications, Santa Fe, NM, USA, 12-13 February 2015; pp. 9-14.

7. Lee, B.-G.; Lee, B.-L.; Chung, W.-Y. Wristband-type driver vigilance monitoring system using smartwatch. IEEE Sens. J. 2015, 15, 5624-5633. [CrossRef]

8. Alghizzawi, M.; Ghani, M.A.; Som, A.P.M.; Ahmad, M.F.; Amin, A.; Bakar, N.A.; Salloum, S.A.; Habes, M. The Impact of Smartphone Adoption on Marketing Therapeutic Tourist Sites in Jordan. Int. J. Eng. Technol. 2018, 7, 91-96. [CrossRef]

9. King, C.E.; Sarrafzadeh, M. A survey of smartwatches in remote health monitoring. J. Healthc. Inform. Res. 2018, 2, 1-24. [CrossRef]

10. Li, X.; Dunn, J.; Salins, D.; Zhou, G.; Zhou, W.; Schüssler-Fiorenza Rose, S.M.; Perelman, D.; Colbert, E.; Runge, R.; Rego, S. Digital health: Tracking physiomes and activity using wearable biosensors reveals useful health-related information. PLoS Biol. 2017, 15, e2001402. [CrossRef]

11. Glowacki, E.M.; Zhu, Y.; Hunt, E.; Magsamen-Conrad, K.; Bernhardt, J.M. Facilitators and barriers to smartwatch use among individuals with chronic diseases: A qualitative study. Available online: https://www.mccombs.utexas.edu/ \{\}/media/ files/msb/centers/healthcareinitiativeresponsive/2016\%20symposium/glowacki_facilitators $\% 20$ and $\% 20$ barriers $\% 20$ to $\% 20$ smartwatch\%20use.pdf (accessed on 12 May 2021).

12. Reeder, B.; David, A. Health at hand: A systematic review of smart watch uses for health and wellness. J. Biomed. Inform. 2016, 63, 269-276. [CrossRef] [PubMed]

13. Årsand, E.; Muzny, M.; Bradway, M.; Muzik, J.; Hartvigsen, G. Performance of the first combined smartwatch and smartphone diabetes diary application study. J. Diabetes Sci. Technol. 2015, 9, 556-563. [CrossRef]

14. Mauldin, T.R.; Canby, M.E.; Metsis, V.; Ngu, A.H.H.; Rivera, C.C. SmartFall: A smartwatch-based fall detection system using deep learning. Sensors 2018, 18, 3363. [CrossRef] [PubMed]

15. Davis, F.D. Perceived Usefulness, Perceived Ease of Use, and User Acceptance of Information Technology. MIS Q. 1989, 13, 319-340. [CrossRef]

16. Salloum, S.A.; Alhamad, A.Q.M.; Al-Emran, M.; Monem, A.A.; Shaalan, K. Exploring students' acceptance of e-learning through the development of a comprehensive technology acceptance model. IEEE Access 2019, 7, 128445-128462. [CrossRef]

17. Kim, K.J.; Shin, D.-H. An acceptance model for smart watches. Internet Res. 2015, 25, 527-541. [CrossRef]

18. Jeong, S.C.; Kim, S.-H.; Park, J.Y.; Choi, B. Domain-specific innovativeness and new product adoption: A case of wearable devices. Telemat. Inform. 2017, 34, 399-412. [CrossRef]

19. Hsiao, K.-L. What drives smartwatch adoption intention? Comparing Apple and non-Apple watches. Libr. Hi Tech 2017, 35, 186-206. [CrossRef]

20. Chuah, S.H.-W.; Rauschnabel, P.A.; Krey, N.; Nguyen, B.; Ramayah, T.; Lade, S. Wearable technologies: The role of usefulness and visibility in smartwatch adoption. Comput. Hum. Behav. 2016, 65, 276-284. [CrossRef]

21. Park, E. User acceptance of smart wearable devices: An expectation-confirmation model approach. Telemat. Inform. 2020, 47, 101318. [CrossRef]

22. Al-Emran, M.; Al-Maroof, R.; Al-Sharafi, M.A.; Arpaci, I. What impacts learning with wearables? An integrated theoretical model. Interact. Learn. Environ. 2020, 1-21. [CrossRef] 
23. Simon, B. Wissensmedien im Bildungssektor. Eine Akzeptanzuntersuchung an Hochschulen. Ph.D. Thesis, Wirtschaftsuniversität Wien, Wien, Austria, 2001.

24. Mathieson, K. Predicting User Intentions: Comparing the Technology Acceptance Model with the Theory of Planned Behavior. Inf. Syst. Res. 1991, 2, 173-191. [CrossRef]

25. Dillon, A.; Morris, M.G. User Acceptance of New Information Technology: Theories and Models; Information Today: Medford, NJ, USA, 1996

26. Taherdoost, H. A review of technology acceptance and adoption models and theories. Procedia Manuf. 2018, 22, 960-967. [CrossRef]

27. Yu-Huei, C.; Ja-Shen, C.; Ming-Chao, W. Why Do Older Adults Use Wearable Devices: A Case Study Adopting the Senior Technology Acceptance Model (STAM). In Proceedings of the 2019 Portland International Conference on Management of Engineering and Technology (PICMET), Portland, OR, USA, 25-29 August 2019; pp. 1-8.

28. Dutot, V.; Bhatiasevi, V.; Bellallahom, N. Applying the technology acceptance model in a three-countries study of smartwatch adoption. J. High Technol. Manag. Res. 2019, 30, 1-14. [CrossRef]

29. Büyüközkan, G.; Güler, M. Smart watch evaluation with integrated hesitant fuzzy linguistic SAW-ARAS technique. Measurement 2020, 153, 107353. [CrossRef]

30. Baudier, P.; Ammi, C.; Wamba, S.F. Differing perceptions of the Smartwatch by users within developed countries. J. Glob. Inf. Manag. 2020, 28, 1-20. [CrossRef]

31. Jeong, M.; Park, K.; Kim, K. A survey of what customers want in smartwatch brand applications. Int. J. Mob. Commun. 2020, 18, 540-558. [CrossRef]

32. Kranthi, A.K.; Ahmed, K.A.A. Determinants of smartwatch adoption among IT professionals-an extended UTAUT2 model for smartwatch enterprise. Int. J. Enterp. Netw. Manag. 2018, 9, 294-316.

33. Choe, M.-J.; Noh, G.-Y. Combined Model of Technology Acceptance and Innovation Diffusion Theory for Adoption of Smartwatch. Int. J. Contents 2018, 14, 32-38.

34. Kim, K.J. Round or square? How screen shape affects utilitarian and hedonic motivations for smartwatch adoption. Cyberpsychol. Behav. Soc. Netw. 2016, 19, 733-739. [CrossRef]

35. Hong, J.-C.; Lin, P.-H.; Hsieh, P.-C. The effect of consumer innovativeness on perceived value and continuance intention to use smartwatch. Comput. Hum. Behav. 2017, 67, 264-272. [CrossRef]

36. Jung, Y.; Perez-Mira, B.; Wiley-Patton, S. Consumer adoption of mobile TV: Examining psychological flow and media content. Comput. Human Behav. 2009, 25, 123-129. [CrossRef]

37. De Wulf, K.; Schillewaert, N.; Muylle, S.; Rangarajan, D. The role of pleasure in web site success. Inf. Manag. 2006, 43, 434-446. [CrossRef]

38. Doll, W.J.; Torkzadeh, G. The measurement of end-user computing satisfaction. MIS Q. 1988, 15, 259-274. [CrossRef]

39. Eiriksdottir, E.; Catrambone, R. Procedural instructions, principles, and examples: How to structure instructions for procedural tasks to enhance performance, learning, and transfer. Hum. Factors 2011, 53, 749-770. [CrossRef] [PubMed]

40. Park, N.; Roman, R.; Lee, S.; Chung, J.E. User acceptance of a digital library system in developing countries: An application of the Technology Acceptance Model. Int. J. Inf. Manag. 2009, 29, 196-209. [CrossRef]

41. Lee, Y.-C. An empirical investigation into factors influencing the adoption of an e-learning system. Online Inf. Rev. 2006, 30, 517-541. [CrossRef]

42. Park, Y.; Son, H.; Kim, C. Investigating the determinants of construction professionals' acceptance of web-based training: An extension of the technology acceptance model. Autom. Constr. 2012, 22, 377-386. [CrossRef]

43. Rogers, E.M. Diffusion of Innovations, 4th ed.; The Free Press: New York, NY, USA, 1995.

44. Lewis, W.; Agarwal, R.; Sambamurthy, V. Sources of influence on beliefs about information technology use: An empirical study of knowledge workers. MIS Q. 2003, 27, 657-678. [CrossRef]

45. Lu, J.; Yao, J.E.; Yu, C.-S. Personal innovativeness, social influences and adoption of wireless Internet services via mobile technology. J. Strateg. Inf. Syst. 2005, 14, 245-268. [CrossRef]

46. Serenko, A. A model of user adoption of interface agents for email notification. Interact. Comput. 2008, 20, 461-472. [CrossRef]

47. Bhatti, T. Exploring factors infuencing the adoption of mobile commerce. J. Internet Bank. Commer. 2007, 12, 1-13.

48. Tan, G.W.-H.; Ooi, K.-B.; Leong, L.-Y.; Lin, B. Predicting the drivers of behavioral intention to use mobile learning: A hybrid SEM-Neural Networks approach. Comput. Hum. Behav. 2014, 36, 198-213. [CrossRef]

49. Cheng, Y.-H.; Huang, T.-Y. High speed rail passengers' mobile ticketing adoption. Transp. Res. Part C Emerg. Technol. 2013, 30, 143-160. [CrossRef]

50. Al-Maroof, R.S.; Salloum, S.A. An Integrated Model of Continuous Intention to Use of Google Classroom. In Recent Advances in Intelligent Systems and Smart Applications; Al-Emran, M., Shaalan, K., Hassanien, A., Eds.; Springer: Cham, Switzerland, 2021; Volume 295.

51. Al-Maroof, R.A.; Arpaci, I.; Al-Emran, M.; Salloum, S.A.; Shaalan, K. Examining the Acceptance of WhatsApp Stickers Through Machine Learning Algorithms. In Recent Advances in Intelligent Systems and Smart Applications; Al-Emran, M., Shaalan, K., Hassanien, A., Eds.; Springer: Cham, Switzerland, 2021; Volume 295.

52. Davis, F.D.; Bagozzi, R.P.; Warshaw, P.R. User acceptance of computer technology: A comparison of two theoretical models. Manage. Sci. 1989, 35, 982-1003. [CrossRef] 
53. Aburayya, A.; Alshurideh, M.; Al Marzouqi, A.; Al Diabat, O.; Alfarsi, A.; Suson, R.; Salloum, S.A.; Alawadhi, D.; Alzarouni, A. Critical success factors affecting the implementation of tqm in public hospitals: A case study in UAE Hospitals. Syst. Rev. Pharm. 2020, 11, 230-242.

54. Terziovski, M. Quality management practices and their relationship with customer satisfaction and productivity improvement. Manag. Res. News 2006, 29, 414-424. [CrossRef]

55. Aburayya, A.; Alshurideh, M.; Albqaeen, A.; Alawadhi, D.; Ayadeh, I. An investigation of factors affecting patients waiting time in primary health care centers: An assessment study in Dubai. Manag. Sci. Lett. 2020, 10, 1265-1276. [CrossRef]

56. Samat, N.; Ramayah, T.; Saad, N.M. TQM practices, service quality, and market orientation. Manag. Res. News 2006, 29, 713-728. [CrossRef]

57. Sit, W.; Ooi, K.; Lin, B.; Chong, A.Y. TQM and customer satisfaction in Malaysia's service sector. Ind. Manag. Data Syst. 2009, 109, 957-975. [CrossRef]

58. Easterby-Smith, M.; Thorpe, R.; Jackson, P.R. Management Research; Sage: Newcastle upon Tyne, UK, $2012 ;$ ISBN 1446260267.

59. Krejcie, R.V.; Morgan, D.W. Determining sample size for research activities. Educ. Psychol. Meas. 1970, 30, 607-610. [CrossRef]

60. Chuan, C.L.; Penyelidikan, J. Sample size estimation using Krejcie and Morgan and Cohen statistical power analysis: A comparison. J. Penyelid. IPBL 2006, 7, 78-86.

61. Al-Emran, M.; Salloum, S.A. Students' Attitudes Towards the Use of Mobile Technologies in e-Evaluation. Int. J. Interact. Mob. Technol. 2017, 11, 195-202. [CrossRef]

62. Rai, R.S.; Selnes, F. Conceptualizing task-technology fit and the effect on adoption-A case study of a digital textbook service. Inf. Manag. 2019, 56, 103161. [CrossRef]

63. Venkatesh, V.; Morris, M.G.; Davis, G.B.; Davis, F.D. User acceptance of information technology: Toward a unified view. MIS Q. 2003, 27, 425-478. [CrossRef]

64. Huang, Y.-M.; Huang, Y.-M.; Huang, S.-H.; Lin, Y.-T. A ubiquitous English vocabulary learning system: Evidence of active/passive attitudes vs. usefulness/ease-of-use. Comput. Educ. 2012, 58, 273-282. [CrossRef]

65. Larsen, T.J.; Sørebø, A.M.; Sørebø, Ø. The role of task-technology fit as users' motivation to continue information system use. Comput. Human Behav. 2009, 25, 778-784. [CrossRef]

66. Mun, Y.Y.; Jackson, J.D.; Park, J.S.; Probst, J.C. Understanding information technology acceptance by individual professionals: Toward an integrative view. Inf. Manag. 2006, 43, 350-363.

67. Salloum, S.A.; Al-Emran, M.; Shaalan, K.; Tarhini, A. Factors affecting the E-learning acceptance: A case study from UAE. Educ. Inf. Technol. 2019, 24, 509-530. [CrossRef]

68. Ringle, C.M.; Wende, S.; Becker, J.-M. SmartPLS 3; SmartPLS: Bönningstedt, Germany, 2015.

69. Hair, J.; Hollingsworth, C.L.; Randolph, A.B.; Chong, A.Y.L. An updated and expanded assessment of PLS-SEM in information systems research. Ind. Manag. Data Syst. 2017, 117, 442-458. [CrossRef]

70. Urbach, N.; Ahlemann, F. Structural equation modeling in information systems research using partial least squares. J. Inf. Technol. Theory Appl. 2010, 11, 5-40.

71. Al-Skaf, S.; Youssef, E.; Habes, M.; Alhumaid, K.; Salloum, S.A. The Acceptance of Social Media Sites: An Empirical Study Using PLS-SEM and ML Approaches. In Advanced Machine Learning Technologies and Applications: Proceedings of AMLTA 2021; Springer: Berlin/Heidelberg, Germany, 2021; Volume 1339, pp. 548-558.

72. Goodhue, D.L.; Lewis, W.; Thompson, R. Does PLS have adavantages for small sample size or non-normal data? MIS Q. 2012, 36, 981-1001. [CrossRef]

73. Barclay, D.; Higgins, C.; Thompson, R. The Partial Least Squares (PLS) Approach to Casual Modeling: Personal Computer Adoption Ans Use as an Illustration. Technol. Stud. 1995, 2, 285-309.

74. Nunnally, J.C.; Bernstein, I.H. Psychometric Theory; McGraw-Hill: New York, NY, USA, 1994; ISBN 0070474656.

75. Kline, R.B. Principles and Practice of Structural Equation Modeling; Guilford Publications: New York, NY, USA, 2015; ISBN 1462523358.

76. Fornell, C.; Larcker, D.F. Evaluating Structural Equation Models With Unobservable Variables and Measurement Error. J. Mark. Res. 1981, 18, 39-50. [CrossRef]

77. Henseler, J.; Ringle, C.M.; Sarstedt, M. A new criterion for assessing discriminant validity in variance-based structural equation modeling. J. Acad. Mark. Sci. 2015, 43, 115-135. [CrossRef]

78. Al-Maroof, R.S.; Salloum, S.A.; Hassanien, A.E.; Shaalan, K. Fear from COVID-19 and technology adoption: The impact of Google Meet during Coronavirus pandemic. Interact. Learn. Environ. 2020. [CrossRef]

79. Kurdi, B.A.; Alshurideh, M.; Salloum, S.A.; Obeidat, Z.M.; Al-dweeri, R.M. An empirical investigation into examination of factors influencing university students' behavior towards elearning acceptance using SEM approach. Int. J. Interact. Mob. Technol. 2020, 14, 19-41. [CrossRef]

80. Alshurideh, M.; Salloum, S.A.; Al Kurdi, B.; Monem, A.A.; Shaalan, K. Understanding the quality determinants that influence the intention to use the mobile learning platforms: A practical study. Int. J. Interact. Mob. Technol. 2019, 13, 157-183. [CrossRef]

81. Alghizzawi, M.; Habes, M.; Salloum, S.A.; Ghani, M.A.; Mhamdi, C.; Shaalan, K. The effect of social media usage on students'elearning acceptance in higher education: A case study from the United Arab Emirates. Int. J. Inf. Technol. Lang. Stud. 2019, 3, 13-26. 
82. Habes, M.; Salloum, S.A.; Alghizzawi, M.; Alshibly, M.S. The role of modern media technology in improving collaborative learning of students in Jordanian universities. Int. J. Inf. Technol. Lang. Stud. 2018, 2, 71-82.

83. Alghizzawi, M.; Salloum, S.A.; Habes, M. The role of social media in tourism marketing in Jordan. Int. J. Inf. Technol. Lang. Stud. 2018, 2, 59-70.

84. Salloum, S.A.; Mhamdi, C.; Al Kurdi, B.; Shaalan, K. Factors affecting the Adoption and Meaningful Use of Social Media: A Structural Equation Modeling Approach. Int. J. Inf. Technol. Lang. Stud. 2018, 2, 96-109.

85. Salloum, S.A.; Al-Emra, M.; Habes, M.; Alghizzawi, M. Understanding the Impact of Social Media Practices on E-Learning Systems Acceptance; Springer: Berlin/Heidelberg, Germany, 2019.

86. Salloum, S.A.; Shaalan, K. Adoption of E-Book for University Students; Springer: Berlin/Heidelberg, Germany, 2019; Volume 845, ISBN 9783319990095.

87. Saeed Al-Maroof, R.; Alhumaid, K.; Salloum, S. The Continuous Intention to Use E-Learning, from Two Different Perspectives. Educ. Sci. 2021, 11, 6. [CrossRef]

88. Zainal, A.Y.; Yousuf, H.; Salloum, S.A. Dimensions of agility capabilities organizational competitiveness in sustaining. In Joint European-US Workshop on Applications of Invariance in Computer Vision; Springer: Berlin/Heidelberg, Germany, 2020; Volume 1153, pp. 762-772.

89. Habes, M.; Alghizzawi, M.; Ali, S.; SalihAlnaser, A.; Salloum, S.A. The Relation among Marketing ads, via Digital Media and mitigate (COVID-19) pandemic in Jordan. Int. J. Adv. Sci. 2020, 29, 2326-12348.

90. Alhashmi, S.F.S.; Alshurideh, M.; Al Kurdi, B.; Salloum, S.A.; Alhashmi, S.F.S.; Alshurideh, M.; Al Kurdi, B.; Salloum, S.A. A Systematic Review of the Factors Affecting the Artificial Intelligence Implementation in the Health Care Sector. In Joint European-US Workshop on Applications of Invariance in Computer Vision; Springer: Berlin/Heidelberg, Germany, 2020 ; pp. 37-49.

91. Alhashmi, S.F.S.; Salloum, S.A.; Abdallah, S. Critical Success Factors for Implementing Artificial Intelligence (AI) Projects in Dubai Government United Arab Emirates (UAE) Health Sector: Applying the Extended Technology Acceptance Model (TAM). In Proceedings of the International Conference on Advanced Intelligent Systems and Informatics 2019, Cairo, Egypt, 26-28 October 2019; pp. 393-405.

92. Salloum, S.A.; Maqableh, W.; Mhamdi, C.; Al Kurdi, B.; Shaalan, K. Studying the Social Media Adoption by university students in the United Arab Emirates. Int. J. Inf. Technol. Lang. Stud. 2018, 2, 83-95.

93. Alshurideh, M.; Al Kurdi, B.; Salloum, S. Examining the Main Mobile Learning System Drivers' Effects: A Mix Empirical Examination of Both the Expectation-Confirmation Model (ECM) and the Technology Acceptance Model (TAM). In Proceedings of the International Conference on Advanced Intelligent Systems and Informatics 2019, Cairo, Egypt, 26-28 October 2019; pp. 406-417.

94. Hair, J.F., Jr.; Hult, G.T.M.; Ringle, C.; Sarstedt, M. A Primer on Partial Least Squares Structural Equation Modeling (PLS-SEM); Sage Publications: Thousand Oaks, CA, USA, 2016; ISBN 1483377466.

95. Senapathi, M.; Srinivasan, A. An empirical investigation of the factors affecting agile usage. In Proceedings of the 18th International Conference on Evaluation and Assessment in Software Engineering, London, UK, 12-14 May 2014 ; p. 10.

96. Chin, W.W. The partial least squares approach to structural equation modeling. Mod. methods Bus. Res. 1998, 295, $295-336$.

97. Rhein, F.E. B2B Innovation Adoption and Diffusion. In The Dynamics of Green Innovation in B2B Industries; Springer: Berlin/Heidelberg, Germany, 2021; pp. 35-56.

98. Wibowo, A.; Chen, S.-C.; Wiangin, U.; Ma, Y.; Ruangkanjanases, A. Customer Behavior as an Outcome of Social Media Marketing: The Role of Social Media Marketing Activity and Customer Experience. Sustainability 2021, 13, 189. [CrossRef]

99. Wang, K.; Zhu, C.; Tondeur, J. Using micro-lectures in small private online courses: What do we learn from students' behavioural intentions? Technol. Pedagog. Educ. 2020, 1-15. [CrossRef]

100. Jimenez, I.A.C.; García, L.C.C.; Violante, M.G.; Marcolin, F.; Vezzetti, E. Commonly Used External TAM Variables in e-Learning, Agriculture and Virtual Reality Applications. Futur. Internet 2021, 13, 7. [CrossRef]

101. Fan, L.; Zhang, X.; Rai, L.; Du, Y. Mobile Payment: The Next Frontier of Payment Systems?-An Empirical Study Based on Push-Pull-Mooring Framework. J. Theor. Appl. Electron. Commer. Res. 2021, 16, 155-169. [CrossRef]

102. Saprikis, V.; Avlogiaris, G.; Katarachia, A. Determinants of the Intention to Adopt Mobile Augmented Reality Apps in Shopping Malls among University Students. J. Theor. Appl. Electron. Commer. Res. 2021, 16, 491-512. [CrossRef]

103. Alfadda, H.A.; Mahdi, H.S. Measuring Students' Use of Zoom Application in Language Course Based on the Technology Acceptance Model (TAM). J. Psycholinguist. Res. 2021, 1-18. [CrossRef]

104. Ozkan-Yildirim, S.; Pancar, T. Smart Wearable Technology for Health Tracking: What Are the Factors that Affect Their Use. In IoT in Healthcare and Ambient Assisted Living; Springer: Berlin/Heidelberg, Germany, 2021; pp. 165-199.

105. Tung, F.-C.; Chang, S.-C.; Chou, C.-M. An extension of trust and TAM model with IDT in the adoption of the electronic logistics information system in HIS in the medical industry. Int. J. Med. Inform. 2008, 77, 324-335. [CrossRef]

106. Zaman, N.; Goldberg, D.M.; Kelly, S.; Russell, R.S.; Drye, S.L. The Relationship between Nurses' Training and Perceptions of Electronic Documentation Systems. Nurs. Rep. 2021, 11, 12-27. [CrossRef]

107. Ghosh, A.; Ahmed, S. Shared Medical Decision-Making and Patient-Centered Collaboration. Mod. Tech. Biosens. 2021, 327, 215-228.

108. Can, Y.S.; Ersoy, C. Privacy-preserving Federated Deep Learning for Wearable IoT-based Biomedical Monitoring. ACM Trans. Internet Technol. 2021, 21, 1-17. [CrossRef] 
109. Iqbal, M.H.; Aydin, A.; Brunckhorst, O.; Dasgupta, P.; Ahmed, K. A review of wearable technology in medicine. J. R. Soc. Med. 2016, 109, 372-380. [CrossRef] [PubMed]

110. Sultan, N. Reflective thoughts on the potential and challenges of wearable technology for healthcare provision and medical education. Int. J. Inf. Manag. 2015, 35, 521-526. [CrossRef]

111. Salmon, J.W.; Thompson, S.L. Big Data: Information Technology as Control over the Profession of Medicine. In The Corporatization of American Health Care; Springer: Berlin/Heidelberg, Germany, 2021; pp. 181-254.

112. Al-Maroof, R.S.; Alfaisal, A.M.; Salloum, S.A. Google glass adoption in the educational environment: A case study in the Gulf area. Educ. Inf. Technol. 2021, 26, 2477-2500. [CrossRef] 